\title{
Metal accumulation in relation to size and body condition in an all-alien species community
}

\author{
Paride Balzani $^{1,2} \cdot$ Antonín Kouba $^{2} \cdot$ Elena Tricarico $^{1} \cdot$ Melina Kourantidou $^{3,4} \cdot$ Phillip J. Haubrock $^{2,5}$ (1)
}

Received: 11 May 2021 / Accepted: 15 November 2021 / Published online: 1 December 2021

(c) Springer-Verlag GmbH Germany, part of Springer Nature 2021

\begin{abstract}
Metal pollution is one of the main environmental threats in freshwater ecosystems. Aquatic animals can accumulate these substances and transfer them across the food web, posing risks for both predators and humans. Accumulation patterns strongly vary depending on the location, species, and size (which in fish and crayfish is related to age) of individuals. Moreover, high metal concentrations can negatively affect animals' health. To assess the intraspecific relationship between metal accumulation and size and health (proxied by the body condition) of individuals, the concentration of 14 metals (Al, As, Cd, Co, Cr, $\mathrm{Cu}, \mathrm{Fe}, \mathrm{Hg}, \mathrm{Mg}, \mathrm{Mn}, \mathrm{Ni}, \mathrm{Pb}, \mathrm{Se}, \mathrm{Zn}$ ) was analyzed in six alien species from the highly anthropogenically altered Arno River (Central Italy): five fish (Alburnus alburnus, Pseudorasbora parva, Lepomis gibbosus, Ictalurus punctatus, and Silurus glanis) and one crayfish (Procambarus clarkii). We found that in P. clarkii, $\mathrm{Cu}$ was negatively related to size, as well as $\mathrm{Al}$ in L. gibbosus and $\mathrm{Mg}$ for adult I. punctatus. Positive size-dependent relationships were found for $\mathrm{Hg}$ in L. gibbosus, Fe in S. glanis, and $\mathrm{Cr}$ in juvenile I. punctatus. Only $\mathrm{Co}$ and $\mathrm{Mg}$ in S. glanis were found to negatively correlate with individual health. Since metal concentrations in animal tissue depend on trade-offs between uptake and excretion, the few significant results suggest different types of trade-offs across different species and age classes. However, only predatory fish species (L. gibbosus, I. punctatus, and S. glanis) presented significant relationships, suggesting that feeding habits are one of the primary drivers of metal accumulation.
\end{abstract}

Keywords Environmental pollution $\cdot$ Bioaccumulation $\cdot$ Fish $\cdot$ Ecotoxicology $\cdot$ Freshwater ecosystems $\cdot$ Metals $\cdot$ Fulton condition factor

Responsible Editor: Severine Le Faucheur

Phillip J. Haubrock

phillip.haubrock@senckenberg.de

1 Department of Biology, University of Florence, Via Madonna del Piano 6, 50019 Sesto Fiorentino, Italy

2 South Bohemian Research Center of Aquaculture and Biodiversity of Hydrocenoses, Faculty of Fisheries and Protection of Waters, University of South Bohemia in České Budějovice, Zátiší 728/II, 38925 Vodňany, Czech Republic

3 Hellenic Center for Marine Research, Institute of Marine Biological Resources and Inland Waters, 16452 Athens, Greece

4 Department of Sociology, Environmental and Business Economics, University of Southern Denmark, Degnevej 14, 6705 Esbjerg $\varnothing$, Denmark

5 Department of River Ecology and Conservation, Senckenberg Research Institute and Natural History Museum Frankfurt, Clamecystrasse 12, 63571 Gelnhausen, Germany

\section{Introduction}

Metal and metalloid (hereafter "metal") pollution is one of the most serious environmental hazards (Gall et al. 2015; Yang et al. 2018), posing both ecological and human health risks (Alhashemi et al. 2012; Liu et al. 2018, 2021). This threat originates from their uptake from the environment and subsequent bioaccumulation in animal tissues over time and their tendency to biomagnify through the transfer along the food chain to higher trophic positions (Markert et al. 2003; Madgett et al. 2021; Yang et al. 2021). While most metals are "essential" (i.e., needed for physiological functions as opposed to "non-essential" metals), high bioaccumulation causes detrimental effects on the health and fitness of aquatic animals (Reddy et al. 1997; Funes et al. 2006; Zeitoun and Mehana 2014; Javed and Usmani 2019), leading to behavioral, biochemical, and histological changes and potentially even death (Has-Schön et al. 2015; Fonseca et al. 2017; Greani et al. 2017). 
Aquatic organisms accumulate metals from their local environment (i.e., water or sediment) either through their gills and skin, or through their digestive system after consumption of contaminated food sources (Squadrone et al. 2013; Has-Schön et al. 2015). Metal concentrations can be affected, among other factors, by the level of environmental contamination and the duration of exposure (Kouba et al. 2010; Has-Schön et al. 2015). Therefore, as organisms grow, it can be expected that larger (i.e., older) individuals have accumulated higher metal concentrations than smaller (i.e., younger) ones. Another factor potentially affecting metal bioaccumulation is the species richness and biomass of the recipient environment (McKinley and Johnston 2010); as prey-rich ecosystems typically have more diverse pathways, metals can more easily transfer along the food chain (Balzani et al. 2021). As such, it can be assumed that generalist predators relying on multiple prey species with diverse metal accumulation levels will express higher accumulation variability depending on the food web complexity, while at the same time differing from specialized consumers (Yevtushenko 1998).

The Arno River in Tuscany is the second biggest river in Central Italy. Particularly in Florence, the Arno River is anthropogenically and hydromorphologically altered (i.e., divided by weirs slowing its flow, channelization). The species community is characterized by a dominance of alien species, which have led to a complete species turnover from a native community to an almost all-alien species assemblage (Haubrock et al. 2021a). The fish assemblage, in particular, is entirely composed of alien species, some of which are considered invasive. Among these alien species, there are the two catfish species, Silurus glanis and Ictalurus punctatus, but also a variety of cyprinids (Alburnus alburnus, Barbus barbus, Cyprinus carpio, Pseudorasbora parva, Tinca tinca; Squalius cephalus) and others (Lepomis gibbosus, Padogobius sp.) (Haubrock et al. 2019a). Among the crustaceans, the invasive Procambarus clarkii and Dikerogammarus villosus are the most prominent in terms of abundance (Haubrock et al. 2019a). The river is contaminated from a variety of substances, comprising drugs (Zuccato et al. 2008), pesticides (Griffini et al. 1997), and metals (Cortecci et al. 2009) from both natural (i.e., weathering of metalbearing rocks) and anthropogenic sources (i.e., industrial and agricultural activities) (Dinelli et al. 2005). In addition to those, nitrate derived from fertilizers, soil-organic, and wastewater origin have also been recorded (Nisi et al. 2005).

Thus far, little is known on how metals accumulate within alien species assemblages and how this may be affected by intraspecific characteristics (Balzani et al. 2021). Since alien species can generally tolerate higher pollutant concentrations than native species (El Haj et al. 2019), studying the sublethal effects on their fitness is an interesting avenue of research. To explore these relationships, we investigated intraspecific relationships for metal bioaccumulation in five fish and one crustacean species among the species present in the Arno River, using the alien species assemblage from this river as a model. We hypothesized that, in each species, larger and thus older individuals will have accumulated higher metal concentrations and that metal concentration will negatively correlate with body condition.

\section{Materials and methods}

\section{Study site and sampling}

The sampling was conducted from April to June 2018 within one stretch of the inner-Florence section of the Arno River (43.765606 N 11.268234 E, 2.4 km length), which is delimitated by weirs (Fig. 1). Fish were caught with standard fishing rods using a variety of baits, and crayfish were caught using funnel traps. Caught fish were immediately euthanized via stunning, followed by gill cutting with a clean ceramic blade, while crayfish were killed by freezing, in compliance with the authorization ("Autorizzazione alla pesca scientifica Regione Toscana"). Samples were stored in ice during transport and then preserved in the freezer at $-20^{\circ} \mathrm{C}$ until further processing. Overall, 110 individuals belonging to five fish and one crustacean alien species were collected: 7 A. alburnus, 4 P. parva, 16 L. gibbosus, 37 S. glanis, 36 I. punctatus, and $10 P$. clarkii. Life stages of I. punctatus were distinguished following Haubrock et al. (2018), with specimens of a total length $>30 \mathrm{~cm}$ considered adults, resulting in a total of 16 juveniles and 20 adults caught. Only adults were caught for the other fish species based on primary and secondary sex characteristics.

For each individual crayfish, we measured the cephalothorax length (CTL; from the tip of the rostrum to the end of carapace, $\mathrm{cm} \pm 0.1$ ), while for each individual fish, we measured weight $(\mathrm{W} ; \mathrm{g} \pm 0.1)$ and total length $(\mathrm{TL}$; from the tip of the snout to the tip of the longer lobe of the caudal fin, $\mathrm{cm} \pm 0.1)$ and calculated the Fulton factor $(K)$, defined as $K=100^{*} \mathrm{~W} / \mathrm{TL}^{3}$. The Fulton factor is a morphometric index of body condition, commonly used as a proxy to assess the health and fitness condition of an individual in relation to the size of the species population (Froese 2006; Nash et al. 2006). Indeed, it is based on the fact that greater body mass at a given length corresponds to better conditions (Schloesser and Fabrizio 2017).

\section{Metal sample preparation and analysis}

For the analysis of metals, a sample of abdominal muscle (for crayfish) and dorsal muscle without skin (for fish) was taken from each specimen. Samples were weighed wet, dried in an oven at $60^{\circ} \mathrm{C}$ for $48 \mathrm{~h}$, and weighed again dry. 
Fig. 1 Map of the study site, which is a $2.4 \mathrm{~km}$ stretch of the Arno River, showing the two weirs (A and B) enclosing the sampling area

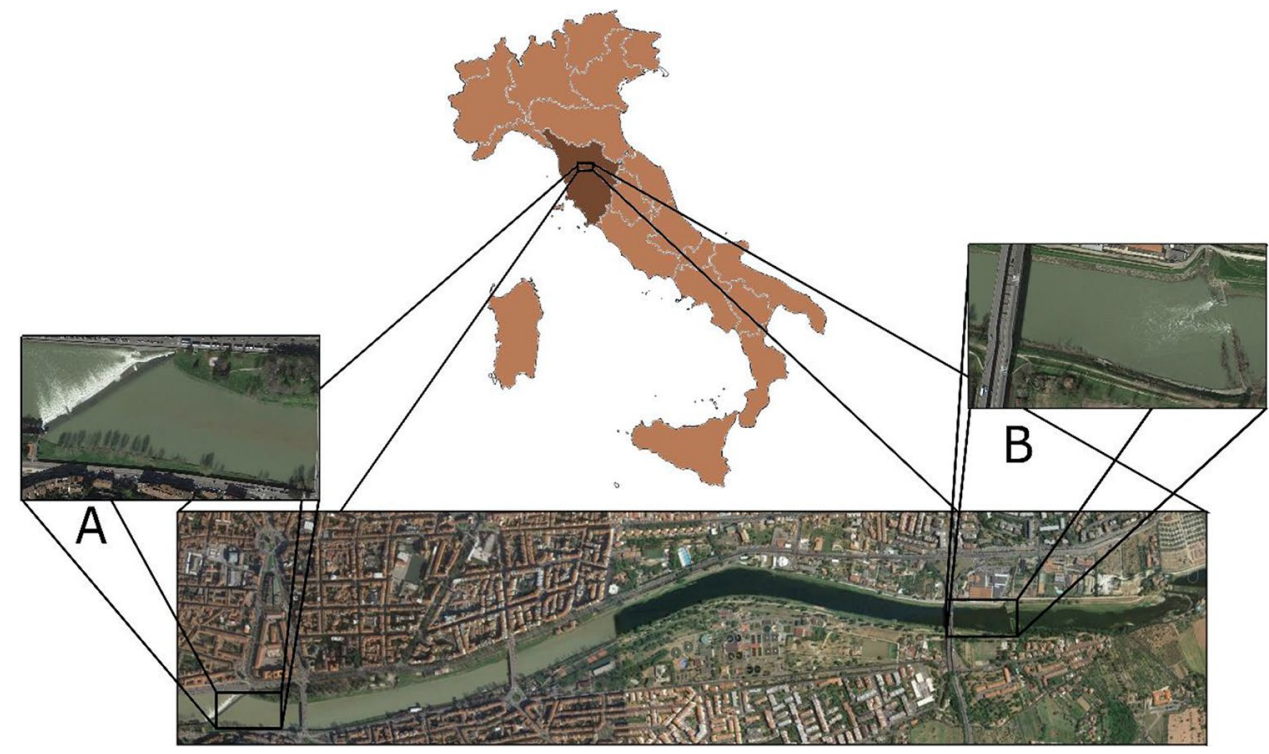

Organic matrices were prepared, weighing 50-500 mg (dry weight). Each sample was diluted in $10 \mathrm{ml}$ of nitric acid, then mineralized with microwave radiation $\left(1600 \mathrm{~W}, 210^{\circ} \mathrm{C}\right.$; Olesik 1991; Low et al. 2009; Ghanthimathi et al. 2012) to homogenize them and subsequently analyzed through Inductively Coupled Plasma - Optical Emission Spectrometry (ICP-OES). A total of 11 blanks (one every approximately 10 samples) were also prepared to control for contamination. Before running the analyses and at the end of each measurement session, certified standards of known metal concentrations (multistandard concentrations: $0.1 \mathrm{ppm}$, $1 \mathrm{ppm}$, and $10 \mathrm{ppm}$; $\mathrm{Hg}$ standard concentrations: $0.01 \mathrm{ppm}$ and $0.05 \mathrm{ppm}$ ) were used to calibrate the instruments and to ensure that no instrumental bias occurred. In compliance with quality assurance and quality control (QA/QC), three replicates for each sample (from the same digestion solution) were run and their relative standard deviations (RSD) were calculated. The respective mean metal concentration was used for further analyses.

For each sample, the following metal concentrations were determined: aluminum ( $\mathrm{Al})$, arsenic (As), cadmium $(\mathrm{Cd})$, cobalt $(\mathrm{Co})$, chromium $(\mathrm{Cr})$, copper $(\mathrm{Cu})$, iron $(\mathrm{Fe})$, mercury (Hg), magnesium (Mg), manganese (Mn), nickel (Ni), lead $(\mathrm{Pb})$, selenium $(\mathrm{Se})$, and zinc $(\mathrm{Zn})$. The analytical detection limit for all metals was $0.01 \mathrm{ppm}$ on a dry weight basis. Concentrations in blanks were $<1 \%$ of the samples, and all the RSDs were $<10 \%$.

\section{Statistical analyses}

Before running statistical analyses, each value of samples that presented metal concentrations below the detection limit (0.01) was substituted with the value of the detection limit itself (Soto et al. 2016) and metal concentrations were $\log _{10}$-transformed to account for multiplicative effects.

To display correlations, an explorative correlation analysis using Spearman's rank correlation was performed ( $R$ package "corrplot"; Wei et al. 2017) for each species. A preliminary linear model on $\log _{10}$-transformed total length and weight was performed for fish. Since a significant relationship was found $\left(F_{1,197}=2460.4, p<0.001\right.$, adj. $\left.R^{2}=0.93\right)$, only total length was used for subsequent analyses. To identify relationships between metal concentrations, size, and body condition, we built a linear model for each species using the "step" function for every $\log _{10}$-transformed metal concentration as response variable and length (TL or CTL) and Fulton factor $(\mathrm{K})$ as predictors. All statistical analyses were performed using the software $\mathrm{R}$ (4.0 version, $\mathrm{R}$ Core Team 2020), and the level of statistical significance $(\alpha)$ was set at $p=0.05$.

\section{Results}

All the correlations of the measured metals with length, weight, and Fulton factor for every species are shown in Fig. 2.

The applied models showed significant relationships for only four species (P. clarkii, L. gibbosus, S. glanis, and I. punctatus). The cyprinid species $A$. alburnus and $P$. parva did not show a significant relationship with any metal (Supplementary information 1). Only a few metals were found to significantly correlate with length $(\mathrm{Cu}$ for $P$. clarkii, $\mathrm{Al}$ and $\mathrm{Hg}$ for L. gibbosus, $\mathrm{Fe}$ for S. glanis, and $\mathrm{Cr}$ and $\mathrm{Mg}$ for juveniles and adults, respectively, of I. punctatus). Only two metals (Co and $\mathrm{Mg}$ ) in one species ( $S$. glanis) were found to significantly affect the species' health as proxied by the 


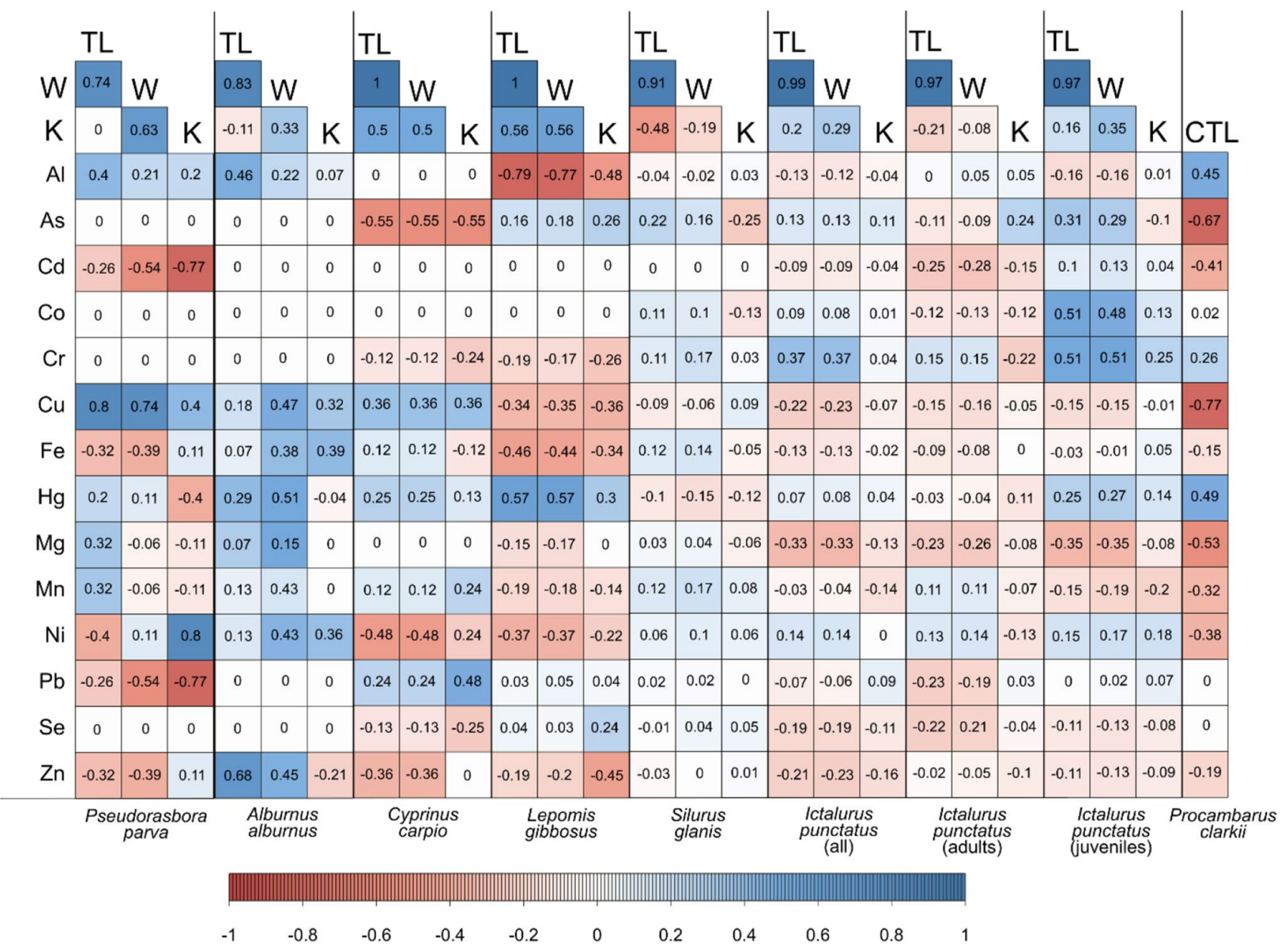

Fig. 2 Correlation plot of all metal concentrations with length (CTL, cephalothorax length for crayfish; TL, total length for fish), weight (W), and Fulton factor $(\mathrm{K})$ for each species

Fulton factor (Table 1). While the relationships with the Fulton factor were both negative, the relationships with length were, depending on the metal, both positive (for $\mathrm{Hg}$ in $L$. gibbosus, $\mathrm{Fe}$ in $\mathrm{S}$. glanis, and $\mathrm{Cr}$ in juvenile I. punctatus) and negative (for $\mathrm{Cu}$ in P. clarkii, $\mathrm{Al}$ in L. gibbosus, $\mathrm{Mg}$ in adult I. punctatus).

\section{Discussion}

There is evidence that some metals bioaccumulate within organisms through time, leading to positive size and agedependent relationships (Dragun et al. 2007; Rajkowska and Protasowicki 2013; Has-Schön et al. 2015). Among these, $\mathrm{Hg}$, one of the most toxic metals even at low concentrations (Kaus et al. 2017; Waheed et al. 2020), is the one that most frequently follows this behavior (Squadrone et al. 2013; Zrnčić et al. 2013; Donadt et al. 2021). However, these relationships are not always obvious. In line with other studies (Jovičić et al. 2015; Léopold et al. 2015;
Jia et al. 2017), we found only a few significant relationships between metal concentrations and total length (a proxy for age). In line with previous literature (Rakocevic et al. 2018), significant relationships were mainly found for essential elements, while no clear or not-significant relationships were found for the non-essentials. The absence of clear patterns is likely due to fish belonging to the same age class (adults) except for I. punctatus, for which comparable concentrations in both young and old animals were found. This latter result could be due to different reasons: the young for higher metabolism and ingestion rate, the old for the longer exposure to pollutants (Yi and Zhang 2012; Liu et al. 2015; Jia et al. 2017), and for predators, the greater consumption of contaminated prey from higher trophic levels (Balzani et al. 2021). Moreover, the variability we identified in the sign of metal-size relationships is also in line with other studies (Jezierska and Witeska 2001; Dragun et al. 2016; Jia et al. 2017). Even the same species can show different accumulation patterns for the same metal depending on the location or 
Table 1 Results of the significant linear models with $\log _{10}$-transformed metal concentration as response variable and length (CTL, cephalothorax length for crayfish; TL, total length for fish) and Fulton factor (K) as predictors

\begin{tabular}{|c|c|c|c|c|c|c|c|c|}
\hline Species & Metal & Covariate & Estimate & Standard error & $t$-value & $p$ & $F$ & Adj. $R^{2}$ \\
\hline \multirow[t]{2}{*}{ Procambarus clarkii } & \multirow[t]{2}{*}{$\mathrm{Cu}$} & Intercept & 2.39 & 0.16 & 15.12 & $<0.001 * * *$ & \multirow[t]{2}{*}{$F_{1,8}=15.89$} & \multirow[t]{2}{*}{0.62} \\
\hline & & CTL & -0.09 & 0.02 & -3.99 & $0.004 * *$ & & \\
\hline \multirow[t]{4}{*}{ Lepomis gibbosus } & \multirow[t]{2}{*}{$\mathrm{Al}$} & Intercept & 2.17 & 0.29 & 7.55 & $<0.001 * * *$ & \multirow[t]{2}{*}{$F_{1,14}=20.55$} & \multirow[t]{2}{*}{0.57} \\
\hline & & $\mathrm{TL}$ & -0.14 & 0.03 & -4.53 & $<0.001 * * *$ & & \\
\hline & \multirow[t]{2}{*}{$\mathrm{Hg}$} & Intercept & -3.24 & 0.78 & -4.17 & $<0.001 * * *$ & \multirow[t]{2}{*}{$F_{1,14}=9.25$} & \multirow[t]{2}{*}{0.35} \\
\hline & & $\mathrm{TL}$ & 0.25 & 0.08 & 3.04 & $<0.01 * *$ & & \\
\hline \multirow[t]{7}{*}{ Silurus glanis } & \multirow[t]{2}{*}{$\mathrm{Co}$} & Intercept & -1.27 & 0.26 & -4.88 & $<0.001 * * *$ & \multirow[t]{2}{*}{$F_{1,35}=6.46$} & \multirow[t]{2}{*}{0.13} \\
\hline & & $\mathrm{K}$ & -1.18 & 0.46 & -2.54 & $0.02 *$ & & \\
\hline & \multirow[t]{2}{*}{$\mathrm{Fe}$} & Intercept & 0.92 & 0.17 & 5.38 & $<0.001 * * *$ & \multirow[t]{2}{*}{$F_{1,35}=4.14$} & \multirow[t]{2}{*}{0.08} \\
\hline & & TL & 0.01 & 0.01 & 2.04 & $0.049^{*}$ & & \\
\hline & \multirow[t]{3}{*}{$\mathrm{Mg}$} & Intercept & 3.53 & 0.20 & 17.74 & $<0.001^{* * *}$ & \multirow[t]{3}{*}{$F_{2,34}=3.94$} & \multirow[t]{3}{*}{0.14} \\
\hline & & $\mathrm{TL}$ & -0.01 & 0.004 & -2.44 & 0.11 & & \\
\hline & & $\mathrm{K}$ & -0.50 & 0.22 & -2.29 & $0.03 *$ & & \\
\hline \multirow{2}{*}{$\begin{array}{l}\text { Ictalurus punctatus (juveniles and } \\
\text { adults) }\end{array}$} & \multirow[t]{2}{*}{$\mathrm{Cr}$} & Intercept & -1.88 & 0.31 & -6.13 & $<0.001 * * *$ & \multirow[t]{2}{*}{$F_{1,34}=13.57$} & \multirow[t]{2}{*}{0.26} \\
\hline & & $\mathrm{TL}$ & 0.03 & 0.01 & 3.68 & $<0.001 * * *$ & & \\
\hline \multirow[t]{2}{*}{ Ictalurus punctatus (juveniles) } & \multirow[t]{2}{*}{$\mathrm{Cr}$} & Intercept & -3.92 & 0.39 & -10.14 & $<0.001 * * *$ & \multirow[t]{2}{*}{$F_{1,14}=51.79$} & \multirow[t]{2}{*}{0.77} \\
\hline & & TL & 0.11 & 0.02 & 7.20 & $<0.001 * * *$ & & \\
\hline \multirow[t]{2}{*}{ Ictalurus punctatus (adults) } & \multirow[t]{2}{*}{$\mathrm{Mg}$} & Intercept & 3.06 & 0.09 & 34.44 & $<0.001 * * *$ & \multirow[t]{2}{*}{$F_{1,18}=10.91$} & \multirow[t]{2}{*}{0.34} \\
\hline & & TL & -0.01 & 0.002 & -3.30 & $<0.01 * *$ & & \\
\hline
\end{tabular}

Asterisks refer to the significance level: $p<0.05(*) ; p<0.01(* *) ; p<0.001(* * *)$

season (Barak and Mason 1990; Farkas et al. 2003; Noël et al. 2013; Ghosn et al. 2020).

Negative relationships are generally more frequent for alkaline elements (e.g., Li, $\mathrm{Na}$, and $\mathrm{K}$ ), whereas positive relationships are more commonly found for transition elements (e.g., Mn, Fe, and Co; Dragun et al. 2016; Jiang et al. 2022). Indeed, we found a negative relationship with the length for $\mathrm{Cu}$ (in P. clarkii) and $\mathrm{Mg}$ (in I. punctatus and $S$. glanis) and positive for Fe (in S. glanis), $\mathrm{Hg}$ (in $L$. gibbosus), and $\mathrm{Cr}$ (in I. punctatus). Partially in line with previous studies (Merciai et al. 2014; Jiang et al. 2022), we found negative relationships with the length for two essential metals $(\mathrm{Cu}$ in P. clarkii and $\mathrm{Mg}$ in I. punctatus and $S$. glanis) and positive relationships for two essential (Fe in S. glanis and $\mathrm{Cr}$ in I. punctatus) and one nonessential metal (Hg in L. gibbosus). Negative relationships could be indicative of faster metabolism in younger fish compared to older ones (Léopold et al. 2015) and higher tissue growing rate than metal uptake rate (Merciai et al. 2014; Dragun et al. 2016). In addition to that, a better metal bioregulation could occur in older fish (De Wet et al. 1994; Merciai et al. 2014). On the other hand, positive relationships can be due to a constant uptake and slow excretion rates (Has-Schön et al. 2015) as metal bioaccumulation depends on a trade-off between uptake and excretion (Adams et al. 2020), suggesting that our findings are likely the outcome of different trade-offs.
Crayfish size is known to correlate with some metal concentrations, especially $\mathrm{Hg}$ (Kouba et al. 2010). However, in this study, we found a significant (negative) relationship only for $\mathrm{Cu}$. Although high $\mathrm{Cu}$ concentrations were found to be detrimental in P. clarkii (Bini and Chelazzi 2006; Zhao et al. 2019a), muscle has a slow $\mathrm{Cu}$ uptake rate compared to other tissues (Soedarini et al. 2012) and $\mathrm{Cu}$ elimination seems to be quite efficient in this species (Zhao et al. 2019b), resulting in low accumulation after exposure (Maranhão et al. 1995).

High metal concentrations within an organism can negatively affect its health (Wu et al. 2016; Fonseca et al. 2017), which can be proxied by the Fulton factor, that is used to assess body conditions (Froese 2006; Mozsár et al. 2015). However, in line with other studies (Jovičić et al. 2015), we found that the Fulton factor was mostly unaffected by metal concentration. The only exceptions were $\mathrm{Mg}$ and $\mathrm{Co}$ in S. glanis, which showed negative relationships, suggesting that life-history changes may play a considerable role. Previous literature showed, however, that this relationship can be highly variable (Alhashemi et al. 2012; Luczynska et al. 2016; Dragun et al. 2016; Rakocevic et al. 2018). One possible explanation is that fish could have physiological mechanisms that reduce the impact of metals on body condition (Tenji et al. 2020). It should also be noted that the Fulton factor is correlated with the body fat content (Schloesser and Fabrizio 2017), which can vary between individuals and species, and that metal accumulation can be positively or 
negatively related to the lipid content, depending on the metal (Sassd 2011; Charette et al. 2021).

Interspecific (as well as intraspecific, among tissues) differences in metal accumulation compared with the environmental concentrations and biomagnification processes in the Arno River community were disentangled in a recent study by Balzani et al. (2021). Nonetheless, by comparing intraspecific relationships, additional information on interspecific patterns can be derived. Interestingly, besides the omnivorous crayfish $P$. clarkii, only predatory fish species presented some significant relationships, whereas the more opportunistic cyprinids (A. alburnus and P. parva) did not. Considered separately, the two age classes of I. punctatus revealed additional information. First, the variance explained for the relationship between $\mathrm{Cr}$ and total length is much higher. Second, the relationship between $\mathrm{Mg}$ and total length was found to be significant for adult specimens. These observations could be due to ontogenetic differences in habitat use, behavior, and diet (Haubrock et al. 2018, 2020, 2021b) that are reflected in different metal accumulations (Balzani et al. 2021). Indeed, I. punctatus juveniles live close to the riverbank and feed more on detritus, while adults live on the bottom and feed in the whole water column (Endo et al. 2015; Haubrock et al. 2020), possibly leading to Cr bioaccumulation in young individuals and a reduction with age in $\mathrm{Mg}$ concentrations in adults. However, S. glanis, which similarly to adults of I. punctatus occupies benthic habitats but expresses pelagic feeding (Haubrock et al. 2020; De Santis and Volta 2021), showed higher Fe bioaccumulation with increasing age. Also, the riparian species L. gibbosus and $P$. clarkii (Donato et al. 2018; Bissattini et al. 2021; Haubrock et al. 2021c) showed negative relationships between metal concentrations and size. Therefore, the role of the living or feeding habitat in bioaccumulation is not straightforward and seems to vary according to the involved species.

Most of the alien species examined in this study have not been subject to management in the Arno River, except for S. glanis, a popular fish among anglers who practice "catch-and-release," which used to be managed in the past (Arlinghaus et al. 2007; Cerri et al. 2018). Additionally, although none of those species is officially known to be harvested for commercial purposes or for human consumption in smaller quantities, anecdotal evidence suggests that the latter may be true (see also Squadrone et al. 2013). The lack of understanding of metal accumulation and interactions with size and body condition or health of these invasive species, together with the lack of management, therefore, poses a simultaneous risk to human health and to the already stressed ecosystem. The results of our study, in combination with earlier works shedding light on trophic interactions (Haubrock et al. 2019a), bioaccumulation and mechanisms through which those metals transfer across food webs to higher trophic levels (Balzani et al. 2021), can provide valuable input not only for conservation authorities concerned with impact mitigation but also for public health and food safety authorities. Indeed, despite the fact that several metal concentrations were found to be below the maximum permitted levels for human consumption as determined by the European Commission (Balzani et al. 2021; European Commission 2008), for metals such as $\mathrm{Hg}$, there is evidence for considerable bioaccumulation across the trophic chain (Balzani et al. 2021). Mercury was also found in this study to have a significant positive relationship with the length of $L$. gibbosus which may indicate for example that any attempts to control the invasion, e.g., through removal/harvesting or other, could be targeted at earlier life stages. This result may also factor into management considerations for $P$. clarkii which is a key prey for L. gibbosus (Haubrock et al. 2019b) and for I. punctatus (adults), for which L. gibbosus is a key prey (Balzani et al. 2021).

At the same time, such works can help build a baseline for understanding interactions between these species and metals in other places where invasive populations have been established. One of the examined species for which significant relationships were identified (P. clarkii), owing to its high impacts and costs (Haubrock et al. 2021d; Kourantidou et al. 2021), is listed among the worst invasive species in Europe (Nentwig et al. 2018) and in the Union list of invasive species of concern attached to the EU Regulation 1143/2014 on invasive alien species (the list of invasive species for which management actions are mandatory). With almost no native fish species left in the Arno River (Balzani et al. 2020; Haubrock et al. 2021a), our finding that predatory fish species were the only ones with significant relationships, suggesting that feeding habitats are likely among the primary drivers of metal accumulation, is key to future restoration initiatives. Indeed, despite the poor environmental quality status of the Arno River, several ecosystem services, which include supporting services related to aquatic biodiversity in the river and its main tributaries, seem to be of great importance to nearby communities (Pacetti et al. 2020), reinforcing the need for restoration actions that require an adequate understanding of the underlying ecological mechanisms.

Last, it should be acknowledged that, in our study, the paucity of significant relationships could be the result of the small sample number, or the too narrow range of sizes sampled, thus representing only one age class. However, the importance of our contribution lies in the use of linear models that help ensure only robust relationships, as opposed to correlation analysis typically used to test such relationships, which can lead to overestimating the significant relationships. Nevertheless, increasing knowledge of patterns of metal bioaccumulation represents an important contribution to the environmental monitoring of freshwater ecosystems. Our work points at the need for more studies comparing 
native and alien populations to help identify stressors that contribute to underlying processes.

Supplementary Information The online version contains supplementary material available at https://doi.org/10.1007/s11356-021-17621-0.

Acknowledgements Heavy metals analyses were performed by Luisa Andrenelli and Susanna Pucci at the Microanalyses Laboratory of the University of Florence. We wish to thank Thomas Busatto, Ivan Fribbi, Francesco Russo, and Mirko Ventrone for helping us with the sampling, and Giuliana Parisi for having allowed us to partly process the samples in her laboratory.

Author contribution PB conceived the study, analyzed the data, and wrote the original draft; PB, AK, ET, and MK interpreted the results; PJH supervised the study. All the authors read and approved the final manuscript.

Funding Open Access funding enabled and organized by Projekt DEAL. Funding was partly provided by the Aquainvad-ED project (2020 Marie Sklodowska-Curie ITN-2014-ETN642197).

Data availability The datasets used and/or analyzed during the current study are available from the corresponding author on reasonable request.

\section{Declarations}

Ethics approval and consent to participate Not applicable.

Consent for publication Not applicable.

Competing interests The authors declare no competing interests.

Open Access This article is licensed under a Creative Commons Attribution 4.0 International License, which permits use, sharing, adaptation, distribution and reproduction in any medium or format, as long as you give appropriate credit to the original author(s) and the source, provide a link to the Creative Commons licence, and indicate if changes were made. The images or other third party material in this article are included in the article's Creative Commons licence, unless indicated otherwise in a credit line to the material. If material is not included in the article's Creative Commons licence and your intended use is not permitted by statutory regulation or exceeds the permitted use, you will need to obtain permission directly from the copyright holder. To view a copy of this licence, visit http://creativecommons.org/licenses/by/4.0/.

\section{References}

Adams W, Blust R, Dwyer R, Mount D, Nordheim E, Rodriguez PH, Spry D (2020) Bioavailability assessment of metals in freshwater environments: a historical review. Environ Toxicol Chem 39:48e59. https://doi.org/10.1002/etc.4558

Alhashemi AH, Karbassi A, Kiabi BH, Monavari SM, Sekhavatjou MS (2012) Bioaccumulation of trace elements in different tissues of three commonly available fish species regarding their gender, gonadosomatic index, and condition factor in a wetland ecosystem. Environ Monit Assess 184:1865e1878. https://doi.org/10. 1007/s10661-011-2085-8
Arlinghaus R, Cooke SJ, Lyman J, Policansky D, Schwab A, Suski C, Sutton SG, Thorstad EB (2007) Understanding the complexity of catch-and-release in recreational fishing: an integrative synthesis of global knowledge from historical, ethical, social, and biological perspectives. Reviews Fish Sci 15:75-167. https://doi.org/10. 1080/10641260601149432

Balzani P, Gozlan RE, Haubrock PJ (2020) Overlapping niches between two co-occurring invasive fish: the topmouth gudgeon Pseudorasbora parva and the common bleak Alburnus alburnus. J Fish Biol 97:1385-1392. https://doi.org/10.1111/jfb.14499

Balzani P, Haubrock PJ, Russo F, Kouba A, Haase P, Veselý L, Masoni A, Tricarico E (2021) Combining metal and stable isotope analyses to disentangle contaminant transfer in a freshwater community dominated by alien species. Environ Pollut 268:115781. https:// doi.org/10.1016/j.envpol.2020.115781

Barak NA-E, Mason CF (1990) Mercury, cadmium and lead in eels and roach: the effects of size, season and locality on metal concentrations in flesh and liver. Sci Total Environ 92:249-256. https://doi. org/10.1016/0048-9697(90)90334-Q

Bini G, Chelazzi G (2006) Acclimatable cardiac and ventilatory responses to copper in the freshwater crayfish Procambarus clarkii. Comp Biochem Physiol C Toxicol Pharmacol 144:235241. https://doi.org/10.1016/j.cbpc.2006.08.014

Bissattini AM, Haubrock PJ, Buono V, Balzani P, Borgianni N, Stellati L, Inghilesi AF, Tancioni L, Martinoli M, Tricarico E, Vignoli L (2021) Trophic structure of a pond community dominated by an invasive alien species: insights from stomach content and stable isotope analyses. Aquat Conserv Mar Freshwat Ecosyst 31:948963. https://doi.org/10.1002/aqc.3530

Cerri J, Ciappelli A, Lenuzza A, Zaccaroni M, Nocita A (2018) Recreational angling as a vector of freshwater invasions in Central Italy: perceptions and prevalence of illegal fish restocking. Knowl Manag Aquat Ecosyst 419:38. https://doi.org/10.1051/kmae/ 2018028

Charette T, Rosabal M, Amyot M (2021) Mapping metal (Hg, As, $\mathrm{Se})$, lipid and protein levels within fish muscular system in two fish species (Striped Bass and Northern Pike). Chemosphere 265:129036. https://doi.org/10.1016/j.chemosphere.2020.129036

Cortecci G, Boschetti T, Dinelli E, Cidu R, Podda F, Doveri M (2009) Geochemistry of trace elements in surface waters of the Arno River Basin, northern Tuscany, Italy. Appl Geochem 24:10051022. https://doi.org/10.1016/j.apgeochem.2009.03.002

De Santis V, Volta P (2021) Spoiled for choice during cold season? habitat use and potential impacts of the invasive Silurus glanis L. in a deep, large and oligotrophic lake (Lake Maggiore, North Italy). https://doi.org/10.20944/preprints202108.0476.v1

De Wet LM, Schoonbee HJ, De Wet LPD, Wild AJB (1994) Bioaccumulation of metals by southern mouthbrooder, Pseudocrenilabrus philander (Weber, 1897) from a mine polluted impoundment. Water SA 20: 119-126. https://doi.org/10.10520/AJA03784738_ 1910

Dinelli E, Cortecci G, Lucchini F, Zantedeschi E (2005) Sources of major and trace elements in the stream sediments of the Arno river catchment (northern Tuscany, Italy). Geochem J 39:531-545. https://doi.org/10.2343/geochemj.39.531

Donadt C, Cooke CA, Graydon JA, Poesch MS (2021) Mercury bioaccumulation in stream fish from an agriculturally-dominated watershed. Chemosphere 262:128059. https://doi.org/10.1016/j.chemo sphere.2020.128059

Donato R, Rollandin M, Favaro L, Ferrarese A, Pessani D, Ghia D (2018) Habitat use and population structure of the invasive red swamp crayfish Procambarus clarkii (Girard, 1852) in a protected area in northern Italy. Knowl Manag Aquat Ecosyst 419:12. https://doi.org/10.1051/kmae/2018002 
Dragun Z, Raspor B, Podrug M (2007) The influence of the season and biotic factors on the cytosolic metal concentrations in the gills of the European chub (Leuciscus cephalus L.). Chemosphere 69:911-919. https://doi.org/10.1016/j.chemosphere.2007.05.069

Dragun Z, Tepić N, Krasnići N, Teskeredžić E (2016) Accumulation of metals relevant for agricultural contamination in gills of European chub (Squalius cephalus). Environ Sci Pollut Res 23:1680216815. https://doi.org/10.1007/s11356-016-6830-y

El Haj Y, Bohn S, Souza MM (2019) Tolerance of native and invasive bivalves under herbicide and metal contamination: an ex vivo approach. Environ Sci Pollut Res 26:31198e31206. https://doi. org/10.1007/s11356-019-06256-x

Endo T, Kaneko S, Igari K, Kanou K, Nakazato R, Kamei R, Usui S, Hyakunari W (2015) Feeding characteristics of the channel catfish Ictalurus punctatus in the littoral zone of Lake Kitaura, Ibaraki Prefecture, Japan. Aquac Sci 63:49e58. https://doi.org/10.11233/ aquaculturesci.63.49

European Commission, 2008. Commission Regulation (EC) No $629 / 2008$ of the European Parliament and of the Council of 2 July 2008 amending Regulation (EC) No 1881/2006 setting maximum levels for certain contaminants in foodstuffs. Off $\mathbf{J}$ Eur Union L $173,6 \mathrm{e} 9$

Farkas A, Salánki J, Specziár A (2003) Age- and size-specific patterns of heavy metals in the organs of freshwater fish Abramis brama L. populating a low-contaminated site. Water Res 37:959-964. https://doi.org/10.1016/S0043-1354(02)00447-5

Fonseca AR, Fernandes LS, Fontainhas-Fernandes A, Monteiro SM, Pacheco FAL (2017) The impact of freshwater metal concentrations on the severity of histopathological changes in fish gills: a statistical perspective. Sci Total Environ 599:217-226. https://doi. org/10.1016/j.scitotenv.2017.04.196

Froese R (2006) Cube law, condition factor and weight-length relationships: history, meta-analysis and recommendations. J Appl Ichthyol 22:241-253. https://doi.org/10.1111/j.1439-0426.2006. 00805.x

Funes V, Alhama J, Navas JI, López-Barea J, Peinado J (2006) Ecotoxicological effects of metal pollution in two mollusc species from the Spanish South Atlantic littoral. Environ Pollut 139:214-223. https://doi.org/10.1016/j.envpol.2005.05.016

Gall JE, Boyd RS, Rajakaruna N (2015) Transfer of heavy metals through terrestrial food webs: a review. Environ Monit Assess 187:187e201. https://doi.org/10.1007/s10661-015-4436-3

Ghanthimathi S, Aminah A, Salmijah S, Ujang T, NurulIzzah A (2012) Comparison of microwave assisted acid digestion methods for ICP-MS determination of total arsenic in fish tissue. Sains Malays 41:1557e1564

Ghosn M, Mahfouz C, Chekri R, Khalaf G, Guérin T, Jitaru P, Amara R (2020) Seasonal and spatial variability of trace elements in livers and muscles of three fish species from the Eastern Mediterranean. Environ Sci Pollut Res 27:12428-12438. https://doi.org/10.1007/ s11356-020-07794-5

Greani S, Lourkisti R, Berti L, Marchand B, Giannettini J, Santini J, Quilichini Y (2017) Effect of chronic arsenic exposure under environmental conditions on bioaccumulation, oxidative stress, and antioxidant enzymatic defenses in wild trout Salmo trutta (Pisces, Teleostei). Ecotoxicology 26:930-941. https://doi.org/10. 1007/s10646-017-1822-3

Griffini O, Bao ML, Barbieri C, Burrini D, Pantani F (1997) Occurrence of pesticides in the Arno river and in potable water-a survey of the period 1992-1995. Bull Environ Contam Toxicol 59:202-209. https://doi.org/10.1007/s001289900465

Has-Schön E, Bogut I, Vuković R, Galović D, Bogut A, Horvatić J (2015) Distribution and age-related bioaccumulation of lead $(\mathrm{Pb})$, mercury $(\mathrm{Hg})$, cadmium $(\mathrm{Cd})$, and arsenic (As) in tissues of common carp (Cyprinus carpio) and European catfish (Sylurus glanis) from the Buško Blato reservoir (Bosnia and Herzegovina).
Chemosphere 135:289-296. https://doi.org/10.1016/j.chemo sphere.2015.04.015

Haubrock PJ, Balzani P, Johovic I, Inghilesi AF, Nocita A, Tricarico E (2018) The diet of the alien channel catfish Ictalurus punctatus in the River Arno (Central Italy). Aquat Invasions 13:575e585. https://doi.org/10.3391/ai.2018.13.4.14

Haubrock PJ, Balzani P, Azzini M, Inghilesi AF, Veselý L, Guo W, Tricarico E (2019a) Shared histories of co-evolution may affect trophic interactions in a freshwater community dominated by alien species. Front Ecol Evol 7:355. https://doi.org/10.3389/fevo.2019. 00355

Haubrock PJ, Balzani P, Criado A, Inghilesi AF, Tricarico E, Monteoliva AP (2019) Predicting the effects of reintroducing a native predator (European eel, Anguilla anguilla) into a freshwater community dominated by alien species using a multidisciplinary approach. Manag Biol Invasions 10:171e191. https://doi.org/10. 3391/mbi.2019.10.1.11

Haubrock PJ, Azzini M, Balzani P, Inghilesi AF, Tricarico E (2020) When alien catfish meet-resource overlap between the North American Ictalurus punctatus and immature European Silurus glanis in the Arno River (Italy). Ecol Freshw Fish 29:4-17. https://doi.org/10.1111/eff.12481

Haubrock PJ, Pilotto F, Innocenti G, Cianfanelli S, Haase P (2021a) Two centuries for an almost complete community turnover from native to non-native species in a riverine ecosystem. Glob Change Biol 27:606-623. https://doi.org/10.1111/gcb.15442

Haubrock PJ, Balzani P, Matsuzaki SIS, Tarkan AS, Kourantidou M, Haase P (2021b) Spatio-temporal niche plasticity of a freshwater invader as a harbinger of impact variability. Sci Total Environ 777:145947. https://doi.org/10.1016/j.scitotenv.2021. 145947

Haubrock PJ, Balzani P, Hundertmark I, Cuthbert RN (2021c) Spatial and size variation in dietary niche of a non-native freshwater fish. Ichthyology \& Herpetology 109:501-506. https://doi.org/10.1643/ i2020099

Haubrock PJ, Cuthbert RN, Tricarico E, Diagne C, Courchamp F, Gozlan RE (2021d) The recorded economic costs of alien invasive species in Italy. NeoBiota 67:247-266. https://doi.org/10.3897/ neobiota.67.57747

Javed M, Usmani N (2019) An overview of the adverse effects of heavy metal contamination on fish health. Proc Natl Acad Sci India B 89:389-403. https://doi.org/10.1007/s40011-017-0875-7

Jezierska B, Witeska M (2001) Accumulation of metals in fish. In: Metal Toxicity to Fish. Widawnictwo Akademii Podlaskiej, Siedlce, pp. 51-106

Jia Y, Wang L, Qu Z, Wang C, Yang Z (2017) Effects on heavy metal accumulation in freshwater fishes: species, tissues, and sizes. Environ Sci Pollut Res 24:9379e9386. https://doi.org/10.1007/ s11356-017-8606-4

Jiang X, Wang J, Pan B, Li D, Wang Y, Liu X (2022) Assessment of heavy metal accumulation in freshwater fish of Dongting Lake, China: effects of feeding habits, habitat preferences and body size. J Environ Sci 112:355-365. https://doi.org/10.1016/j.jes.2021.05. 004

Jovičić K, Nikolić DM, Višnjić-Jeftić Ž, Đikanović V, Skorić S, Stefanović SM, Lenhardt M, Hegediš A, Krpo-Ćetković J, Jarić I (2015) Mapping differential elemental accumulation in fish tissues: assessment of metal and trace element concentrations in wels catfish (Silurus glanis) from the Danube River by ICP-MS. Environ Sci Pollut Res 22:3820-3827. https://doi.org/10.1007/ s11356-014-3636-7

Kaus A, Schäffer M, Karthe D, Büttner O, von Tümpling W, Borchardt D (2017) Regional patterns of heavy metal exposure and contamination in the fish fauna of the Kharaa River basin (Mongolia). Reg Environ Change 17:2023-2037. https://doi.org/10.1007/ s10113-016-0969-4 
Kouba A, Buřič M, Kozák P (2010) Bioaccumulation and effects of heavy metals in crayfish: a review. Water Air Soil Pollut 211:5-16. https://doi.org/10.1007/s11270-009-0273-8

Kourantidou M, Cuthbert RN, Haubrock PJ, Novoa A, Taylor NG, Leroy B, Capinha C, Renault D, Angulo E, Diagne C, Courchamp F (2021) Economic costs of invasive alien species in the Mediterranean basin. NeoBiota 67:427-458. https://doi.org/10.3897/ neobiota.67.58926

Léopold EN, Jung MC, Emmanuel EG (2015) Accumulation of metals in three fish species from the Yaounde Municipal Lake in Cameroon. Environ Monit Assess 187:1-12. https://doi.org/10.1007/ s10661-015-4781-2

Liu J-L, Xu X-R, Ding Z-H, Peng J-X, Jin M-H, Wang Y-S, Hong Y-G, Yue W-Z (2015) Heavy metals in wild marine fish from South China Sea: levels, tissue-and species-specific accumulation and potential risk to humans. Ecotoxicology 24:1583-1592. https:// doi.org/10.1007/s10646-015-1451-7

Liu Y, Liu G, Yuan Z, Liu H, Lam PK (2018) Heavy metals (As, Hg and $\mathrm{V}$ ) and stable isotope ratios (d13C and $\mathrm{d} 15 \mathrm{~N})$ in fish from Yellow River Estuary, China. Sci Total Environ 613:462e471. https://doi.org/10.1016/j.scitotenv.2017.09.088

Liu J, Liu R, Yang Z, Kuikka S (2021) Quantifying and predicting ecological and human health risks for binary heavy metal pollution accidents at the watershed scale using Bayesian Networks. Environ Pollut 269:116125. https://doi.org/10.1016/j.envpol. 2020.116125

Low K, Zain SM, Abas MR, Mohd A (2009) Evaluation of closed vessel microwave digestion of fish muscle with various solvent combinations using fractional factorial design. ASM Sci J 3:71e76

Luczynska J, Luczynski MJ, Paszczyk B (2016) Assessment of mercury in muscles, liver and gills of marine and freshwater fish. $\mathrm{J}$ Elemen 21. https://doi.org/10.5601/jelem.2015.20.2.879

Madgett AS, Yates K, Webster L, McKenzie C, Moffat CF (2021) The concentration and biomagnification of trace metals and metalloids across four trophic levels in a marine food web. Mar Pollut Bull 173:112929. https://doi.org/10.1016/j.marpolbul.2021.112929

Maranhão P, Marques JC, Madeira V (1995) Copper concentrations in soft tissues of the red swamp crayfish Procambarus clarkii (Girard, 1852), after exposure to a range of dissolved copper concentrations. Freshwater Crayfish 10:282-286

Markert BA, Breure AM, Zechmeister HG (2003). Bioindicators and biomonitors. Principles, concepts and applications. Elsevier, Science Ltd, Netherlands

McKinley A, Johnston EL (2010) Impacts of contaminant sources on marine fish abundance and species richness: a review and metaanalysis of evidence from the field. Mar Ecol Prog Ser 420:175191. https://doi.org/10.3354/meps08856

Merciai R, Guasch H, Kumar A, Sabater S, García-Berthou E (2014) Trace metal concentration and fish size: variation among fish species in a Mediterranean river. Ecotoxicol Environ Saf 107:154161. https://doi.org/10.1016/j.ecoenv.2014.05.006

Mozsár A, Boros G, Sály P, Antal L, Nagy SA (2015) Relationship between Fulton's condition factor and proximate body composition in three freshwater fish species. J Appl Ichthyol 31:315-320. https://doi.org/10.1111/jai.12658

Nash RD, Valencia AH, Geffen AJ (2006) The origin of Fulton's condition factor-setting the record straight. Fisheries 31:236-238

Nentwig W, Bacher S, Kumschick S, Pyšek P, Vilà M (2018) More than "100 worst" alien species in Europe. Biol Invasions 20:16111621. https://doi.org/10.1007/s10530-017-1651-6

Nisi B, Vaselli O, Buccianti A, Silva SR (2005) Sources of nitrate in the Arno River waters: constraints from d $15 \mathrm{~N}$ and d $18 \mathrm{O}$. GeoActa 4:13-24

Noël L, Chekri R, Millour S, Merlo M, Leblanc J-C, Guérin T (2013) Distribution and relationships of $\mathrm{As}, \mathrm{Cd}, \mathrm{Pb}$ and $\mathrm{Hg}$ in freshwater fish from five French fishing areas. Chemosphere 90:1900-1910. https://doi.org/10.1016/j.chemosphere.2012.10.015

Olesik JW (1991) Elemental analysis using ICP-OES and ICP/MS. Anal Chem 63:12Ae21A

Pacetti T, Castelli G, Bresci E, Caporali E (2020) Water values: participatory water ecosystem services assessment in the Arno River basin, Italy. Water Resour Manage 34:4527-4544. https://doi.org/ 10.1007/s11269-020-02684-4

R Core Team (2020). R: a language and environment for statistical computing. R Foundation for Statistical Computing. Vienna, Austria. https://www.R-project.org/. Accessed 2 Feb 2021

Rajkowska M, Protasowicki M (2013) Distribution of metals (Fe, Mn, $\mathrm{Zn}, \mathrm{Cu}$ ) in fish tissues in two lakes of different trophy in Northwestern Poland. Environ Monit Assess 185:3493-3502. https:// doi.org/10.1007/s10661-012-2805-8

Rakocevic J, Sukovic D, Maric D (2018) Distribution and relationships of eleven trace elements in muscle of six fish species from Skadar Lake (Montenegro). Turkish J Fish Aquat Sci 18:647-657. https:// doi.org/10.4194/1303-2712-v18_5_01

Reddy PS, Tuberty SR, Fingerman M (1997) Effects of cadmium and mercury on ovarian maturation in the red swamp crayfish, Procambarus clarkii. Ecotoxicol Environ Saf 37:62-65. https://doi. org/10.1006/eesa.1997.1523

Sassd SM (2011) Heavy metals accumulation in common fish species inhabiting Lake Edku and their relation to lipid content and liver size. In Proceedings of the 4th Global Fisheries and Aquaculture Research Conference, the Egyptian International Center for Agriculture, Giza, Egypt, 3-5 October 2011 (pp. 139-150). Massive Conferences and Trade Fairs

Schloesser RW, Fabrizio MC (2017) Condition indices as surrogates of energy density and lipid content in juveniles of three fish species. Trans Am Fish Soc 146:1058-1069. https://doi.org/10.1080/ 00028487.2017 .1324523

Soedarini B, Klaver L, Roessink I, Widianarko B, Van Straalen NM, Van Gestel CAM (2012) Copper kinetics and internal distribution in the marbled crayfish (Procambarus sp.). Chemosphere 87:333-338. https://doi.org/10.1016/j.chemosphere.2011.12.017

Soto DX, Benito J, Gacia E, García-Berthou E, Catalan J (2016) Trace metal accumulation as complementary dietary information for the isotopic analysis of complex food webs. Methods Ecol Evol 7:910e918. https://doi.org/10.1111/2041-210X.12546

Squadrone S, Prearo M, Brizio P, Gavinelli S, Pellegrino M, Scanzio T, Guarise S, Benedetto A, Abete MC (2013) Heavy metals distribution in muscle, liver, kidney and gill of European catfish (Silurus glanis) from Italian Rivers. Chemosphere 90:358e365. https://doi. org/10.1016/j.chemosphere.2012.07.028

Tenji D, Micic B, Sipos S, Miljanovic B, Teodorovic I, Kaisarevic S (2020) Fish biomarkers from a different perspective: evidence of adaptive strategy of Abramis brama (L.) to chemical stress. Environ Sci Eur 32:1-15. https://doi.org/10.1186/s12302-020-00316-7

Waheed R, El Asely AM, Bakery H, El-Shawarby R, Abuo-Salem M, Abdel-Aleem N, Malhat F, Khafaga A, Abdeen A (2020) Thermal stress accelerates mercury chloride toxicity in Oreochromis niloticus via up-regulation of mercury bioaccumulation and HSP70 mRNA expression. Sci Total Environ 718:137326. https://doi.org/ 10.1016/j.scitotenv.2020.137326

Wei T, Simko V, Levy M, Xie Y, Jin Y, Zemla J (2017) Package 'corrplot.' Statistician 56:e24

Wu X, Cobbina SJ, Mao G, Xu H, Zhang Z, Yang L (2016) A review of toxicity and mechanisms of individual and mixtures of heavy metals in the environment. Environ Sci Pollut Res 23:8244-8259. https://doi.org/10.1007/s11356-016-6333-x

Yang Q, Li Z, Lu X, Duan Q, Huang L, Bi J (2018) A review of soil heavy metal pollution from industrial and agricultural regions in China: pollution and risk assessment. Sci Total Environ 642:690e700. https://doi.org/10.1016/j.scitotenv.2018.06.068 
Yang C, Zhang Z, Liu Y, Shan B, Yu W, Li H, Sun D (2021) Heavy metal pollution and stable isotope ratios $\left(\delta^{13} \mathrm{C}\right.$ and $\left.\delta^{15} \mathrm{~N}\right)$ in marine organisms from the Northern Beibu Gulf, South China Sea. Mar Pollut Bull 166:112230. https://doi.org/10.1016/j.marpolbul.2021. 112230

Yevtushenko NY (1998) Accumulation of microelements in organs and tissues of fishes differing in feeding specialization under conditions of cultivation in fishponds with heated water. Hydrobiol $\mathrm{J}$ 34:112-124. https://doi.org/10.1615/HydrobJ.v34.i4-5.110

Yi Y-J, Zhang S-H (2012) Heavy metal (Cd, Cr, Cu, Hg, Pb, Zn) concentrations in seven fish species in relation to fish size and location along the Yangtze River. Environ Sci Pollut Res 19:3989-3996. https://doi.org/10.1007/s11356-012-0840-1

Zhao D, Zhang X, Li X, Ru S, Wang Y, Yin J, Liu D (2019a) Oxidative damage induced by copper in testis of the red swamp crayfish Procambarus clarkii and its underlying mechanisms. Aquat Toxicol 207:120-131. https://doi.org/10.1016/j.aquatox.2018.12.006

Zhao D, Zhang X, Liu D, Ru S (2019b) Cu accumulation, detoxification and tolerance in the red swamp crayfish Procambarus clarkii.
Ecotoxicol Environ Saf 175:201-207. https://doi.org/10.1016/j. ecoenv.2019.03.031

Zeitoun MM, Mehana EE (2014) Impact of water pollution with heavy metals on fish health: overview and updates. Glob Vet 12:219 231. https://doi.org/10.5829/idosi.gv.2014.12.02.82219

Zrnčić S, Oraić D, Ćaleta M, Mihaljević Ž, Zanella D, Bilandžić N (2013) Biomonitoring of heavy metals in fish from the Danube River. Environ Monit Assess 185:1189-1198. https://doi.org/10. 1007/s10661-012-2625-x

Zuccato E, Castiglioni S, Bagnati R, Chiabrando C, Grassi P, Fanelli R (2008) Illicit drugs, a novel group of environmental contaminants. Water Res 42:961-968. https://doi.org/10.1016/j.watres. 2007.09.010

Publisher's note Springer Nature remains neutral with regard to jurisdictional claims in published maps and institutional affiliations. 